\title{
PENGARUH KONSUMSI MINYAK GORENG YANG DIFORTIFIKASI VITAMIN A TERHADAP KADAR RETINOL AIR SUSU IBU
}

\author{
Dewi Permaesih ${ }^{1}$, Yuniar Rosmalina', Sherry A. Tanumihardjo² \\ ${ }_{1}^{1}$ Pusat Teknologi Terapan Kesehatan dan Epidemiologi Klinik \\ 2University of Wisconsin, Madison-USA \\ dpermaesih2002@yahoo.com
}

\begin{abstract}
ABSTRAK
Air Susu Ibu (ASI) merupakan sumber energi, zat gizi penting, air, faktor imun, dan komponen lain yang diperlukan bayi yang memberi perlindungan pada bayi agar tidak kekurangan zat gizi termasuk kekurangan vitamin A. Pada penelitian ini dilakukan pemberian minyak goreng yang difortifikasi vitamin $\mathrm{A}$ dan minyak goreng biasa pada ibu nifas di masyarakat. Ibu nifas dengan umur bayi 14-28 hari dipilih secara acak untuk menerima minyak goreng yang difortifikasi atau tidak difortikasi selama 80 hari dan diikuti periode "wash out" selama 10 hari. Setelah intervensi selesai, rerata kadar retinol dalam Air Susu Ibu pada kedua kelompok menurun, masing masing 3,6 $\mu \mathrm{g} / \mathrm{dL}$ untuk kelompok fortifikasi dibandingkan dengan $5,3 \mu \mathrm{g} / \mathrm{dL}$ pada kelompok tidak fortifikasi. Tidak ada perbedaan rerata kadar retinol yang nyata pada kedua kelompok tersebut. Hal ini menunjukkan bahwa kelompok yang mendapat minyak goreng yang difortifikasi sedikit lebih menguntungkan dibandingkan dengan kelompok yang mendapat minyak yang tidak difortifikasi, karena penurunan kadar vitamin A-nya lebih kecil.
\end{abstract}

Kata kunci: retinol ASI, ibu nifas, fortifikasi

\section{ABSTRACT}

\section{THE EFFECT OF VITAMIN A FORTIFIED COOKING OIL ON BREASTMILK RETINOL STATUS}

Breastmilk is a source of energy, essential nutrients including vitamin A, water, immune factors, and many other components that are beneficial for infants. Breastmilk protects babies against vitamin $A$ deficiency. The efficacy of maternal postpartum intervention with Vitamin A Fortified Cooking Oil on breast milk retinol concentration were assessed based on double-blind community trial. At 14-28 days postpartum women were randomly assigned to receive either Vitamin A fortified cooking oil or non fortified cooking oil for 80 days followed by wash out period of 10 days. After intervention, the mean of breast milk retinol concentration in both groups decreased, $3,6 \mu \mathrm{g} / \mathrm{dL}$ compared with $5,3 \mu \mathrm{g} / \mathrm{dL}$, however, they were not significantly different among two groups. This implied that the group received fortified cooking oil was more advantaged than other group who received non fortified cooking oil

Keywords: breast milk retinol, postpartum women, fortification

\section{PENDAHULUAN}

$\mathrm{V}$ itamin A pada bayi diperlukan untuk kesehatan, pertumbuhan dan perkembangan. Status vitamin A pada kebanyakan bayi yang baru dilahirkan adalah marginal dan ibu nifas umumnya tidak mendapatkan asupan vitamin A yang cukup, karena itu berisiko untuk mengalami kurang Vitamin A. Wanita yang menyusui memiliki resiko kekurangan vitamin $A$ dikarenakan sejumlah vitamin A dikeluarkan melalui Air Susu lbu (ASI). Asupan vitamin A yang tidak memadai untuk menggantikan vitamin $A$ yang disekresi dan ditransfer kepada bayi melalui ASI akan menurunkan cadangan Vitamin A pada ibu, sehingga akan mengalami deplesi dan ASI yang dihasilkan berkurang kualitas vitamin Anya. ${ }^{1}$

ASI merupakan sumber asupan utama bagi bayi. Hasil penelitian Dijkhuizen et al. 2 di perdesaan Kabupaten Bogor menemukan kandungan vitamin A dalam ASI sebesar 11,1 $\mu \mathrm{g} / \mathrm{dL}$ sedangkan Permaesih ${ }^{3}$ di Serang menemukan sebesar $16,5 \mu \mathrm{g} / \mathrm{dL}$. Nilai ini di bawah nilai normal menurut WHO yaitu sebesar $30 \mu \mathrm{g} / \mathrm{dL}$. Batas serum retinol bayi dari ibu yang saat hamil yang ditentukan oleh WHO, 1997 yaitu sebesar $20 \mu \mathrm{g} / \mathrm{dL} .{ }^{4}$

Menurut beberapa peneliti, pada saat menyusui tubuh ibu mampu menghasilkan ASI yang cukup mengandung zat-zat gizi esensial 
walaupun pada saat itu tubuh ibu sedang mengalami kekurangan ${ }^{6}$, namun beberapa penelitian menunjukkan adanya hubungan yang erat antara asupan makanan ibu menyusui dengan kandungan vitamin A pada ASI. Peningkatan status vitamin A pada ibu menyusui maupun balita diketahui memberi pengaruh menguntungkan terhadap morbiditas dan mortalitas ${ }^{7.8,9,10}$.

Konsentrasi retinol dalam air susu ibu dapat menjadi indikasi saat status vitamin A ibu suboptimal, ibu menyusui memproduksi ASI dengan kadar retinol yang makin menurun. Kondisi ini menggambarkan ketidakcukupan asupan makanan saat kehamilan dan ketidakcukupan cadangan vitamin A tubuh. Konsentrasi retinol ASI juga dapat digunakan untuk indikator tidak langsung status vitamin $A$ bayi yang disusui ${ }^{11}$. Menurut Miller et al. ${ }^{12}$ selama masa menyusui ibu dengan status gizi baik memberikan sekitar $750 \mu \mathrm{mol}$ vitamin $A$ melalui ASI yang dikonsumsi sebanyak $130 \mathrm{~L}$, dengan kandungan vitamin $A$ dalam ASI sebesar $1,92 \mu \mathrm{mol} / \mathrm{L}$. Sedangkan ibu nifas dinegara berkembang hanya memberi setengah dari jumlah tersebut, karena kandungan vitamin A dalam ASI nya kurang dari 1,05 $\mu \mathrm{mol} / \mathrm{L}$.

Kandungan retinol pada ASI yang bervariasi berhubungan dengan status vitamin A dan masa menyusui. Pada ibu yang sehat, kolostrum mengandung $151 \mu \mathrm{g} / 100 \mathrm{ml}$ vitamin $\mathrm{A}, \mathrm{ASI}$ masa transisi mengandung $88 \mu \mathrm{g} / 100 \mathrm{ml}$ vitamin A dan ASI yang sudah mature $75 \mu \mathrm{g}$ $/ 100 \mathrm{ml}$ vitamin A. ${ }^{13}$

Strategi mengatasi masalah kurang vitamin A dilakukan melalui program fortifikasi vitamin $\mathrm{A}$ yang merupakan strategi jangka panjang sehingga diharapkan mampu mempertahankan kebutuhan vitamin A tubuh secara berkesinambungan. Minyak goreng merupakan salah satu pangan pembawa yang dipilih untuk program fortifikasi karena dikonsumsi secara luas oleh masyarakat dan diproduksi oleh relatif sedikit industri (terutama minyak sawit) dan dengan skala besar. Selain itu telah dikembangkan teknologi fortifikasi vitamin A pada minyak goreng. Saat ini dipasaran mudah menemukan minyak goreng yang sudah difortifikasi vitamin $\mathrm{A}$.

Analisis dilakukan untuk mengkaji efikasi minyak goreng yang difortifikasi vitamin A kadar retinol dalam ASI.

\section{METODE PENELITIAN}

Penelitian ini adalah efikasi studi, dengan melakukan "eksperimental trial" yang dilakukan di masyarakat dengan "double blind". Penelitian ini terdiri dari 4 perlakuan dan alokasi sampel ke dalam kelompok perlakuan tersebut dilakukan secara acak (random assignment). Namun artikel ini hanya membahas pengaruh pemberian minyak goreng difortifikasi vitamin $\mathrm{A}$ dan tidak difortifikasi terhadap kadar retinol dalam ASI.

Minyak goreng untuk intervensi mempunyai wadah, bentuk dan ukuran yang sama, sehingga masing-masing sampel tidak mengetahui macam perlakuan yang diterimanya. Demikian pula didalam pelaksanaan intervensi, bidan/kader petugas distribusi, asisten peneliti, asisten dan petugas laboratorium tidak mengetahui masing-masing perlakuan. Studi ini sudah mendapatkan ethical clearance dari Badan Penelitian dan Pengembangan Kesehatan, Departemen Kesehatan (Balitbangkes Depkes) Nomor : LB.03.04/KE/1341/2008.

Penelitian dilakukan di empat wilayah puskesmas yaitu Puskemas Cikole, Puskesmas Pandeglang, Puskesmas Kadu Hejo dan Puskesmas Cimanuk di Kabupaten Pandeglang pada bulan Mei 2008. Lama pemberian intervensi dilaksanakan selama 80 hari, dilanjutkan dengan periode 'washout' selama 10 hari. Sampel ASI yang diperoleh dari subjek penelitian ini dibawa ke Puslitbang Gizi Bogor untuk dianalisis.

Populasi penelitian adalah ibu yang menyusui bayi umur 14-28 hari, dimana ASI sudah melewati masa kolostrum dan memasuki masa ASI maturasi namun ibu masih dalam periode masa nifas, sedangkan sampel penelitian adalah ibu menyusui bayi umur 14-28 hari yang memenuhi kriteria inklusi.

Sampel penelitian ini adalah populasi yang memenuhi kriteria inklusi sebagai berikut: a) Ibu menyusui bayinya, b) Ibu dan bayi sehat secara klinis, c) Bersedia ikut dalam penelitian selama 100 hari, d) Tinggal di wilayah penelitian dan e) Bersedia menandatangani formulir persetujuan setelah penjelasan PSP setelah membaca/mendengarkan naskah penjelasan penelitian.

Sampel mempunyai unit yang sama dan besarnya ditetapkan berdasarkan kandungan 
variabel retinol dalam ASI. Dengan menggunakan rumus besar sampel untuk variabel respons kontinyu, rata-rata dua kelompok independen, dengan simpangan baku perubahan kandungan retinol dalam ASI pada penelitian terdahulu (Permaesih 2005) sebesar $8,5 \mu \mathrm{g} / \mathrm{dL}$, tingkat kemaknaan $5 \%$ dan kekuatan uji $95 \% \quad(\beta=0,05)$ serta perbedaan/kenaikan antar kelompok yang diharapkan sebesar 8 $\mu \mathrm{g} / \mathrm{L}$, didapatkan sampel 26 orang ibu nifas. ${ }^{15}$

Sebelum perlakuan, subjek/sampel diambil ASI-nya, disebut ASI 0 (data dasar) dan setiap kelompok diberi bahan intervensi, minyak fortifikasi dan minyak non fortifikasi selama 80 hari. Setelah 80 hari, intervensi dihentikan dan dilakukan "washout" yaitu pembebasan asupan bahan intervensi selama 10 hari.

Kemudian, dilakukan pengumpulan data yaitu pengukuran anthropometri ibu (berat badan dan tinggi badan), pemeriksaan klinis umum, wawancara untuk mendapatkan data karakteristik responden, recall asupan makanan, dilakukan pengambilan ASI. ASI yang diambil sebanyak $10 \mathrm{~mL}$, kemudian disimpan dalam vial-vial sesuai dengan jenis analisa yang akan dilakukan. Untuk setiap jenis analisa disiapkan sampel dalam vial cadangan. Sampel disimpan dalam cool box agar terhindar dari sinar matahari. Selama menunggu proses untuk analisis sampel disimpan dalam freezer dengan suhu $-20^{\circ} \mathrm{C}$.

Untuk penentuan kadar vitamin $A$, penelitian ini menggunakan metode MRDR (the modified-relative-dose-response). Hasil analisis akan memberikan gambaran kadar retinol (R) ASI. Untuk menghindari adanya pengaruh dari asupan bahan makanan lain, saat dilakukan pengumpulan data awal dan data akhir disediakan makanan khusus yang tidak mengandung vitamin $\mathrm{A}$, dan setelah pemberian suplementasi dilakukan "washout" selama 10 hari. ${ }^{15}$

Minyak yang difortifikasi mengandung 25 ppm vitamin $A$, dikemas dalam botol plastik bening dalam bentuk sama dengan yang tidak difortifikasi. Perbedaan hanya diketahui oleh seorang petugas dan dibuka pada akhir penelitian. Untuk menghindari cahaya matahari saat pendistibusian maka botol plastik itu disimpan dalam kantong plastik warna hitam. Distribusi dilakukan oleh petugas dilakukan setiap minggu sekali dengan memberi sebanyak 2 liter untuk setiap keluarga (dihitung berdasarkan besar keluarga dan perkiraan kebutuhan setiap 2 minggu). Petugas bertanggung jawab untuk mencatat jumlah minyak yang diberikan, jumlah penggunaan minyak dikeluarga, menimbang sisa minyak goreng dalam kemasan, menerima sisa minyak tersebut dan menyerahkan pada peneliti untuk dianalisa dan ditimbang, menanyakan cara penyimpanan dirumah tangga, penjelasan cara penggunaan minyak goreng, jenis masakan yang biasa dikonsumsi menggunakan minyak goreng, cara pemasakan, frekuensi penggunaan minyak goreng (berapa kali minyak tersebut dipanaskan) jumlah anggota keluarga yang mengkonsumi, alasan tidak mengkonsumsi dan asupan makanan responden diluar rumah.

Data klinis dilakukan dengan pemeriksaan kesehatan oleh seorang dokter yang meliputi pemeriksaan fisik, anamnesa keluhan dan riwayat penyakit. Data antropometri meliputi berat badan dan tinggi badan. Untuk penimbangan berat badan digunakan alat timbang SECA dengan ketelitian $0,1 \mathrm{~kg}$ dan alat ukur tinggi badan menggunakan microtoise yang mempunyai ketelitian $0,1 \mathrm{~cm}$. Pengumpulan data dilakukan 2 kali yaitu pada awal sebelum intervensi dan pada hari ke 90 .

Data lain yang diambil meliputi karakteristik ibu menyusui meliputi besar keluarga, pendidikan, pekerjaan, retinol $\mathrm{ASI}$, asupan vitamin $A$, kandungan minyak dalam makanan yang digoreng, kandungan vitamin A dalam minyak goreng. Sebelum pengumpulan data dilakukan, calon responden diberi penjelasan umum tentang rencana penelitian yang akan dilakukan. Setelah diberi penjelasan dan responden bersedia untuk ikut dalam penelitian, mereka diminta untuk mengisi formulir kesediaan untuk mengikuti penelitian dengan sukarela. Seminggu sebelum pemeriksaan mereka diberi obat cacing, dan sehari sebelum pemeriksaan mereka diminta berpuasa pada malam hari hingga pagi hari saat pemeriksaan,

Data asupan minyak goreng dilakukan dengan menghitung dari jumlah minyak yang terserap dalam makanan yang dikonsumsi. Data asupan vitamin A dari makanan dihitung dari hasil wawancara recall makanan. Analisa sumber asupan vitamin A dibagi dalam 2 jenis yaitu sumber bahan makanan hewani dan nonhewani (sayuran, buah-buahan dan lainnya). Minyak yang dikonsumsi dihitung berdasarkan 
jumlah serapan minyak yang digunakan dalam proses pemasakan.

Pengolahan dan analisis data untuk memberi gambaran hasil penelitian, menjawab pertanyaan dan tujuan penelitian dilakukan secara bertahap, mulai dari pembuatan formulir, pengumpulan data di lapangan hingga data siap dianalisis. Pada data yang dikumpulkan di lapangan dilakukan pengeditan (editing), pengkodean (coding) dan pemasukan data ke dalam komputer (entry data). Data yang sudah ada dalam komputer dilakukan pembersihan data (cleaning) dengan cara melihat kesesuaian dengan kondisi, distribusi frekuensi setiap peubah. Bila ditemukan adanya kesalahan atau kejanggalan pada saat memasukkan data, dilakukan pengecekan ulang pada kuesioner.

\section{HASIL}

\section{Karakteristik Sampel}

Sampel penelitian adalah ibu nifas yang tinggal di wilayah kerja Puskesmas Cikole, Puskesmas Pandeglang, Puskesmas Kadu Hejo dan Puskesmas Cimanuk Kabupaten Pandeglang. Hingga akhir penelitian jumlah data yang dapat dianalisis untuk dua kelompok ini adalah sebanyak 56 orang, masing-masing kelompok 28 ibu nifas. Umur ibu nifas terbanyak berada pada kelompok umur $\leq 30$ tahun yaitu sebanyak 34 orang $(60,1 \%)$ dan sisanya kelompok umur $>30$ tahun $(39,9 \%)$. Analisis statistik mendapatkan hasil yang tidak bermakna $(p>0,05)$.

Faktor lain yang juga dapat berpengaruh pada menyusui adalah berapa jumlah anak yang pernah dilahirkan atau paritas. Hasil analisis menunjukkan masih banyak ibu dengan jumlah anak lebih dari 2 yaitu sebanyak 33 ibu (59\%).

Pola menyusui ibu juga dipengaruhi oleh faktor pendidikan. Lama pendidikan dibagi dalam 2 kategori yaitu $\leq 6$ tahun dan lebih dari 6 tahun. Sebaran tingkat pendidikan menunjukkan masih rendahnya tingkat pendidikan dari ibu nifas yang menjadi sampel pada penelitian ini, lama pendidikan ibu yang terbanyak adalah pada kategori $\leq 6$ tahun yaitu sebanyak 67 ibu $(58,8 \%)$.

\section{Gambaran Konsumsi Minyak Selama Masa Perlakuan}

Minyak yang dikonsumsi oleh sampel berasal dari dua sumber yaitu makanan yang dimasak dengan minyak goreng dirumah dan makanan yang sudah matang. Untuk mengetahui gambaran jumlah konsumsi minyak yang dikonsumsi ibu nifas dalam rumah tangga dilakukan recall konsumsi makanan sebanyak tiga kali.

Recall awal dan akhir menggambarkan jumlah konsumsi minyak yang berasal dari rumah tangga, sedang recall minggu ke 6 dan ke 8 menggambarkan konsumsi minyak yang diberikan dalam penelitian ini. Minyak yang difortifikasi vitamin $A$, berbeda dalam penyerapan minyak makanan yang digoreng, karena itu dalam perhitungan dugaan jumlah minyak yang dikonsumsi digunakan jumlah minyak yang diserap oleh bahan makanan yang dikonsumsi. Tabel 1 menunjukkan rerata konsumsi minyak goreng selama masa perlakuan.

Kenaikan konsumsi minyak goreng pada minggu ke 6 dibandingkan dengan awal perlakuan pada kelompok perlakuan 7,5 gram dan antara minggu 8 dan awal perlakuan adalah sebesar 7,7 gram, sedangkan pada kelompok yang mengonsumsi minyak goreng tidak difortifikasi peningkatannya lebih besar masingmasing 12 gram dan 12,6 gram.

\section{Asupan Energi dan Zat Gizi}

Konsumsi minyak tentunya disertai dengan konsumsi makanan. Hasil analisis asupan energi dan zat gizi lainnya diambil dari data yang sama dengan data konsumsi minyak. Rerata asupan energi pada seluruh sampel sebesar $2446 \pm 486$ kkal dengan rentang nilai 1321-3333 kkal. Bila dibandingkan dengan Angka Kecukupan Gizi (AKG), jumlah ini sudah mencapai sebesar 100\%. Ibu nifas pada kelompok penelitian ini sudah mencukupi kebutuhan energinya. Hasil uji statistik mendapatkan nilai $p>0,05$ yang menunjukkan tidak ada perbedaan yang bermakna. Tabel 2 menunjukkan rerata asupan zat gizi pada kedua kelompok. Dari hasil pengamatan dan wawancara dengan sampel, umumnya ibu nifas diwilayah tersebut pantang mengkonsumsi makanan tertentu, seperti misalnya telur dan hati, baik itu hati ayam maupun hati sapi yang 
merupakan sumber protein dan vitamin A yang cukup baik.

Tabel 2 menunjukkan pada kedua kelompok, konsumsi bahan makanan nabati lebih tinggi dibandingkan sumber bahan makanan hewani. Hasil uji statistik menunjukkan tidak ada perbedaan jumlah zat gizi yang dikonsumsi.

Tabel 1

Rerata Konsumsi Minyak Goreng selama Masa Perlakuan

\begin{tabular}{lccc}
\hline \multirow{2}{*}{ Konsumsi Minyak } & \multicolumn{2}{c}{ Kelompok (gram) } & \multirow{2}{*}{$\mathrm{p}$} \\
\cline { 2 - 3 } & Minyak Fortifikasi & Minyak Tidak Fortifikasi & \\
\hline Awal & $31,8 \pm 13$ & $31,7 \pm 16,7$ & 1,0 \\
Minggu 6 & $39,3 \pm 10,5$ & $43,7 \pm 15,6$ & 0,52 \\
Minggu 8 & $39,5 \pm 16,4$ & $44,4 \pm 19,5$ & 0,21 \\
\hline
\end{tabular}

Tabel 2

Rerata Asupan Energi dan Zat Gizi Lainnya menurut Kelompok Perlakuan

\begin{tabular}{lccc}
\hline \multirow{2}{*}{ Asupan } & \multicolumn{2}{c}{ Kelompok } & $p$ \\
\cline { 2 - 3 } & Fortifikasi & Non-fortifikasi & \\
\hline Energi (kkal) & $2469 \pm 467$ & $2423 \pm 504$ & 0,56 \\
Protein hewani (g) & $21 \pm 10,7$ & $20,8 \pm 10,6$ & 0,20 \\
Protein nabati (g) & $47,8 \pm 14,5$ & $45 \pm 14,9$ & 0,42 \\
Protein total (g) & $68,8 \pm 16$ & $65,8 \pm 18,7$ & 0,07 \\
Lemak (g) & $34,6 \pm 20$ & $38,4 \pm 21,1$ & 0,2 \\
Besi hewani (mg) & $3,2 \pm 3,6$ & $3,1 \pm 2$ & 0,6 \\
Besi nabati (mg) & $23,7 \pm 11,2$ & $33,3 \pm 18,3$ & 0,09 \\
Besi total (mg) & $27 \pm 10,5$ & $36,4 \pm 17,7$ & 0,09 \\
\hline
\end{tabular}

Tabel 3

Rata-Rata Asupan Vitamin A dan Tingkat Kecukupannya menurut Kelompok Perlakuan

\begin{tabular}{lccc}
\hline \multirow{2}{*}{ Konsumsi Minyak } & \multicolumn{2}{c}{ Kelompok (gram) } & \\
\cline { 2 - 3 } & Minyak Fortifikasi & Minyak Tidak Fortifikasi & \\
\hline Vitamin A (RE) & $88 \pm 90$ & $86 \pm 80$ & 0,642 \\
Karoten (RE) & $356 \pm 247$ & $405 \pm 258$ & 0,697 \\
Asupan vitamin A & $444 \pm 241$ & $491 \pm 282$ & 0,930 \\
$\%$ AKG & $52 \pm 28$ & $58 \pm 33$ & 0,620 \\
Minyak goreng (RE) & $717 \pm 255$ & 0 & \\
Total asupan (RE) & $1161 \pm 376$ & $491 \pm 282$ & $0,000^{*}$ \\
$\%$ AKG total & $137 \pm 44$ & $58 \pm 33$ & $0,000^{*}$ \\
\hline
\end{tabular}




\section{Asupan Vitamin A}

Asupan vitamin A dari makanan pada seluruh sampel dinilai dari pencatatan konsumsi makan pada saat pelaksanaan intervensi berjalan, yaitu minggu ke 6 dan minggu ke 8 . Hasil perhitungan asupan vitamin A dibagi berdasarkan sumber makanan yaitu sumber makanan hewani dan yang berasal dari nonhewani (sayuran, buah dan bahan nabati lain) karoten. Untuk perhitungan asupan vitamin A didasarkan pada unit satuan Retinol Equivalent (RE). Perhitungan selanjutnya didasarkan pada jumlah total konsumsi asupan dari kedua bahan makanan tersebut. Untuk kelompok yang mendapat minyak yang difortifikasi vitamin $\mathrm{A}$, asupan vitamin $A$ dari minyak ditambahkan pada total asupan.

Kandungan vitamin A dalam minyak goreng yang difortifikasi adalah $25 \mathrm{RE} / \mathrm{g}$, sedangkan kandungan vitamin $\mathrm{A}$ dalam minyak yang tidak difortifikasi $0 \mathrm{RE} / \mathrm{g}$. Dengan memperhitungkan kerusakan vitamin $\mathrm{A}$ dalam pemasakan ratarata 30 persen, maka asupan vitamin $\mathrm{A}$ dari minyak adalah jumlah rata-rata minyak yang dikonsumsi kali kandungan vitamin $\mathrm{A}$ dalam minyak. Hasil analisis kandungan vitamin $A$ yang telah digunakan untuk dua kali menggoreng mendapatkan nilai rata-rata sebesar 18,8RE/g.

\section{Status Vitamin A}

Hasil analisis status vitamin A dibagi dalam 3 bagian yaitu kadar retinol ASI (R), kadar didehydroretinol (vitamin $A 2=D R$ ) dan rasio antara DR:R. Dalam tulisan ini yang disampaikan adalah hasil pemeriksaan kadar retinol dalam ASI.

Status vitamin A dapat diketahui dengan menganalisis sampel darah maupun ASI. Pada penelitian ini dilakukan analisis pada ASI dengan menggunakan metode analisis yang dikembangkan oleh Tanumihardjo dan Penniston. ${ }^{16}$ Prinsip dari analisis ini adalah sama dengan uji MRDR (The-Modified-relativedose-response) pada darah yang telah digunakan secara luas untuk menghitung cadangan Vitamin A secara kualitatif di dalam organ hati manusia maupun hewan dengan status kesehatan defisien hingga normal. Vitamin A diambil oleh kelenjar mamae dari kilomikra atau holo-RBP dan disekresikan ke dalam ASI sebagai ester Vitamin A. Penanda vitamin $A$ berhasil diamati pada air susu bayi DR telah dideteksi di dalam ASI (Tanumihardjo, pengamatan pribadi). Nilai $D R: R$ dari sampel susu dapat merepresentasikan status vitamin $A$ jika nilai tersebut berkorelasi dengan kandungan serum yang melampaui kisaran cadangan vitamin A di dalam hati. Analisis DR pada ASI manusia belum banyak dilakukan. Pada penelitian ini pengambilan sampel ASI dilakukan setelah 6-7 jam pemberian DRA (3,4didehydro retynil asetat).

Konsentrasi vitamin A di dalam ASI menawarkan peluang yang unik untuk menilai status wanita hamil dan mengekstrapolasinya ke status bayi. Pengambilan sampel ASI dinilai tidak invasif, lebih mudah dan diterima secara budaya dibandingkan dengan pengambilan darah.

\section{Kadar retinol (R) ASI}

Kadar retinol ASI pada hasil analisis seluruh sampel ASI mendapatkan sebesar $19,4 \pm 8,5 \mu \mathrm{g} / \mathrm{dL}$, rentang nilai dari 1,6 $38,9 \mu \mathrm{g} / \mathrm{dL}$, sedangkan pada kedua kelompok perlakuan ditemukan nilai sebesar 18,9 $\mu \mathrm{g} / \mathrm{dL}$.Nilai ini lebih tinggi dari yang ditemukan pada ibu nifas di Serang yaitu sebesar 16,5 $\mu \mathrm{g} / \mathrm{dL}$, (Permaesih et al) ${ }^{3}$ dan dengan di Bogor sebesar $11,1 \mu \mathrm{g} / \mathrm{dL}$ Dijkhuizen et. $A^{2}{ }^{2}$. Nilai ratarata kadar retinol ASI masih dibawah indikator yang dianjurkan WHO,1997 sebesar $20 \mu \mathrm{g} / \mathrm{dL}$.

Pada Gambar 1 terlihat bahwa pada kelompok fortifikasi terjadi rerata penurunan kadar retinol pada ASI sebesar 3,6 RE sedangkan pada kelompok non fortifikasi rerata penurunannya lebih banyak, yaitu 5,3 RE. Dengan demikian kelompok ibu yang mengkonsumsi minyak dengan fortifikasi vitamin A mempunyai penurunan yang lebih sedikit dari pada kelompok non fortifikasi.

Bila sampel dikelompokkan menurut nilai normal WHO,1997 hasil analisis menunjukkan sebanyak orang 33 ibu nifas $(58,9 \%)$ berada pada nilai kurang dan sisanya sebanyak 40,1 persen berada pada nilai lebih. Hasil analisis distribusi responden menurut batasan kadar retinol ASI-WHO,1997 disajikan pada Tabel 4. 


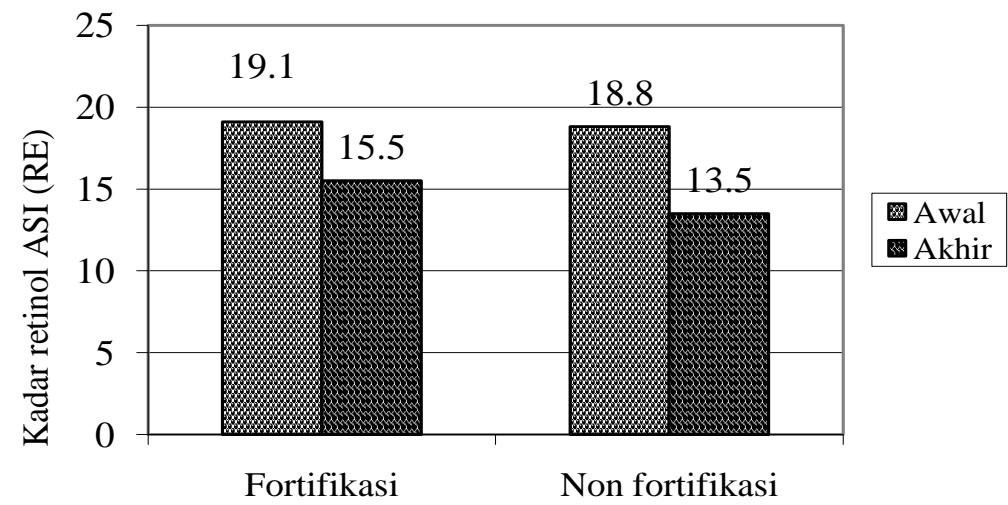

Gambar 1

Kadar Retinol ASI Sebelum dan Sesudah Intervensi

Tabel 4

Distribusi Responden menurut Batasan Kadar Retinol ASI-WHO dan Kelompok Perlakuan Sebelum dan Sesudah

\begin{tabular}{lcc}
\hline \multirow{2}{*}{ Variabel } & \multicolumn{2}{c}{ Kelompok } \\
\cline { 2 - 3 } & Minyak Fortifikasi & Minyak Tidak Fortifikasi \\
\hline Awal & $16(57,1)$ & $17(60,7)$ \\
$<20 \mu \mathrm{g} / \mathrm{dL} \mathrm{n}(\%)$ & $12(42,9)$ & $11(39,3)$ \\
$\geq 20 \mu \mathrm{g} / \mathrm{dL} \mathrm{n}(\%)$ & & \\
Akhir & $21(75)$ & $23(82,1)$ \\
$<20 \mu \mathrm{g} / \mathrm{dL} \mathrm{n}(\%)$ & $7(25$ & $5(17,9)$ \\
$\geq 20 \mu \mathrm{g} / \mathrm{dL} \mathrm{n}(\%)$ & & \\
\hline
\end{tabular}

Tabel 4 menunjukkan pada akhir penelitian jumlah ibu nifas dengan kadar retinol berada pada nilai normal yang dianjurkan WHO, 1997 semakin banyak. Dari 57 persen menjadi 75 persen pada kelompok yang mendapat minyak yang difortifikasi dan dari 60,7 persen menjadi 82,1 persen pada kelompok yang mendapat minyak yang tidak difortifikasi.

\section{BAHASAN}

Peningkatan kadar retinol dalam tubuh dapat dilakukan antara lain dengan mengonsumsi makanan yang tinggi kandungan vitamin A. Sumber bahan makanan dapat berasal dari makanan hewani seperti hati, telur, sayuran berwarna hijau, buah-buaham. Upaya lain melakukan fortifikasi pada bahan makanan yang banyak dikonsumsi oleh penduduk. Minyak goreng salah satu bahan makanan cocok sebagai wahana fortifikasi. Saat ini banyak dipasaran banyak ditemukan minyak goreng yang sudah difortifikasi. Semua anggota keluarga dalam rumah tangga tentu mengonsumsi minyak goreng, termasuk ibu nifas.

Penelitian menunjukkan adanya hubungan yang erat antara asupan makanan ibu menyusui dengan kandungan vitamin A pada ASI Dengan demikian, minyak goreng yang difortifikasi vitamin $A$, bila dikonsumsi oleh ibu nifas tentu akan mempengaruhi kadar vitamin $\mathrm{A}$ dalam tubuh ibu nifas termasuk dalam kadar ASI. Peningkatan status vitamin A pada ibu menyusui maupun balita diketahui memberi pengaruh menguntungkan terhadap morbiditas dan mortalitas. $7,8,9,10$.

Jumlah vitamin A yang masuk dalam tubuh dari minyak yang dikonsumsi tergantung dari jumlah yang masuk melalui makanan, dan dari bahan makanan lainnya. Hasil analisis konsumsi makanan sehari-hari menunjukkan asupan vitamin $\mathrm{A}$ baik karoten maupun vitamin A masih rendah, dibawah kecukupan yang 
dianjurkan. Hasil analisis retinol ASI pada awal penelitian pada seluruh sampel sebagian besar dibawah nilai normal yang dianjurkan WHO, 1997, demikian pula pada akhir penelitian. Kondisi ini terjadi pada kedua kelompok. Rendahnya kadar retinol ASI pada sampel penelitian ini selain secara fisiologis kadar retinol ASI menurun seiring dengan bertambahnya umur bayi juga kemungkinan periode "washouf" selama 10 hari. Konsumsi minyak goreng yang difortifikasi, walaupun jumlahnya sudah melebihi nilai Angka Kecukupan Vitamin A belum mampu untuk meningkatkan kadar retinol ASI, namun penurunan kadar retinol ASI lebih sedikit dibandingkan dengan penurunan retinol pada ibu nifas yang mendapat minyak goreng yang tidak difortifikasi.

Menurut Haskell dan Brown ${ }^{1}$ wanita yang menyusui memiliki resiko kekurangan vitamin $A$ dikarenakan sejumlah vitamin $A$ disekresikan kedalam ASI jika konsumsi vitamin A tidak memadai untuk menggantikan vitamin $A$ yang disekresi dan ditransfer kepada bayi melalui ASI, maka cadangan vitamin A pada ibu akan mengalami deplesi. Asupan vitamin A makanan pada ibu nifas sampel ini berada di bawah batas AKG, baru 60 persen. Rendahnya asupan antara lain dipengaruhi kebiasaan yang ada dimasyarakat, yang membatasi jenis bahan makanan yang dikonsumsi ibu nifas. Asumsi lain adalah batasan yang digunakan, $20 \mu \mathrm{g} / \mathrm{dL}$ tidak sesuai, karena analisis kadar retinol ASI menggunakan metoda yang tidak sama.

\section{SIMPULAN DAN SARAN}

\section{Simpulan}

Kadar rata-rata retinol ASI pada sampel penelitian ini masih berada dibawah nilai normal yang dianjurkan oleh WHO yaitu sebesar $\mu \mathrm{g} / \mathrm{dL}$ kemudian turun menjadi $16,7 \mu \mathrm{g} / \mathrm{dL}$

\section{Saran}

Perlu pengkajian yang lebih mendalam untuk meninjau kembali manfaat minyak yang difortifikasi vitamin A terhadap kadar vitamin A dalam ASI pada masa nifas. Mengingat masih rendahnya kadar retinol ASI pada ibu nifas, promosi peningkatan konsumsi makanan sumber vitamin A masih perlu ditingkatkan lagi.

\section{UCAPAN TERIMAKASIH}

Disampaikan terimakasih kepada seluruh tim yang terlibat dalam proses penelitian ini, tim peneliti pusat baik yang terlibat di lapangan maupun di laboratorium, ibu nifas yang WHO/UNICEF/IVACG. 1997. Task Force. Vitamin A supplement: a giude to their use in the treatment and prevention of vitamin $A$ deficiency and Xeroftalmia. Geneva: WHO.

\section{RUJUKAN}

1. Haskel MJ, Brown KH. Maternal Vitamin A Nutriture and The Vitamin A Content of Human Milk. Jurnal of Mamary Gland Biology and Neoplasia 1999; 4(3):243-257.

2. Dijkhuizen MA, Wieringa FT, West CE, Muherdiyantiningsih, Muhilal. Concurrent micronutrient deficiencies in lactating mothers and their infants in Indonesia. Am. J. Nutr. 2001: 73 (4):786-790.

3. Permaesih D. Pengaruh pemberian vitamin A $2 \times 200000$ SI pada ibu nifas terhadap kandungan retinol ASI dan morbiditas bayi. Laporan Penelitian. Bogor: Puslitbang Gizi dan Makanan, 2005.

4. WHO/UNICEF/IVACG. Vitamin A supplement: a giude to their use in the treatment and prevention of vitamin $\mathrm{A}$ deficiency and Xeroftalmia. Geneva: WHO, 1997.

5. Abdulla EM, Zaidi FE, Zaidi A. Immune factors in Breast Milk: A study and review. Pak J Med Sci.2005; 21(2): 178-86.

6. Roy SK, Islam A, Molla A, Akramuzzaman SM, Jahan F, Fuchs $G$. Impact of a single megadose of vitamin $A$ at delivery on breastmilk of mother and morbidity of their infants. European Journal of Clinical Nutrition. 1997; 51(5): 302-307.

7. Bhaskaram P, Balakrishna N. Effect of administration of $200,000 \mathrm{IU}$ of vitamin A to women within $24 \mathrm{hrs}$ after delivery on response to PPV administered to the newborn. Indian Pediatr.1998; 35(3): 217222.

8. Rice AL, Stoltzfus RJ, de Fransisco A, Chakraborty J, Kjolhede C L, Wahed MA. Maternal vitamin A or beta-carotene supplementation in lactating bangladeshi women benefits mothers and infants but 
does not prevent subclinical deficiency. J. Nutr. 1999;129(2):356-365.

9. Stoltzfus RJ, Hakimi M, Miller KW, Rasmussen KM, Dawiesah S, Habicht JP, et al.. High Dose Vitamin A Supplementation of Breast Feeding Indonesian Mothers: Effects on the Vitamin A Status of Mothers and Infants. J. Nutr. 1993, 123(4) :666-675.

10. Gibson, R.S. Principles of Nutritional Assessment. Second Edition. New York: Oxford Press, 2005.

11. Miller M, Humprey J, Johnson E, Marinda E, Brookmeyer R, Katz J. Why Do Children Become Vitamin A Deficient? Proceeding of the XX International Vitamin A Consultative Group Meeting. J. Nutr.2002; 132(9 Suppl):2867s-2880s.

12. Ross JS, Harvey PWJ. Contribution of breastfeeding to vitamin $A$ nutrition of infants a simulation model. Bulletin of World Health Organization 2003; 8(2)1:80-86

13. Lemeshow S,Hosmer, DW, Klar J,Lwanga SK. Adequacy of sample size in health studies. Geneve: WHO, 1990.

14. van Jaarsveld $P J$, Faber $M$, Tanumihardjo S.A, Nestel P., Lombard C. J, Benadé AJS. Carotene-rich orange-fleshed sweet potato improves the vitamin A status of primary school children assessed with the modifiedrelative-dose-response test. Am J Clin Nutr. 2005; 81(5):1080 -1087

15. Tanumihardjo SA, Penniston KL. Simplified methodology to determine breast milk retinol consentrations. J Lipid Res.2002;43(2):350-355

16. Wasantwisut, E. Recommendations for Monitoring and Evaluating Vitamin A Programs: Outcome Indicators. J. Nutr.2002; 132(9Suupl): 2940S-2942S. 
